\title{
A case of pachydermodactyly in a 16 year-old male
}

\author{
J Madruga Dias ${ }^{1 *}$, M Manuela Costa ${ }^{1}$, J Romeu' ${ }^{1}$ L Soares de Almeida², P Filipe ${ }^{2}$, JA Pereira da Silva ${ }^{1}$ \\ From 18th Pediatric Rheumatology European Society (PReS) Congress \\ Bruges, Belgium. 14-18 September 2011
}

\section{Background}

Pachydermodactyly is a rare benign superficial fibromatosis, aetiology unknown, characterized by asymmetric painless swelling of the proximal interphalangeal (PIF) joints of the hands, most frequently in adolescent males. Radiographs and MRI show only soft tissue thickening. Histological exam reveals epidermic hiperplasia, collagen fibers and fibroblast proliferation and increased mucin deposition.

\section{Aim}

Report a case of Pachydermodactyly.

\section{Methods}

Analysis of the patient's clinical record.

\section{Results}

A 16 year-old caucasian male was sent to our department due to swelling of the lateral and dorsal regions of the metacarpophalangic (MCF) and interphalagic joints of the hands, with 3 years of progression. The swelling started on the $3^{\text {rd }}$ PIF joint of the left hand. In 3 months all left hand PIF and MCF joints were affected. Three years later similar lesions appeared in the right hand ( $2^{\text {nd }}$ and $5^{\text {th }}$ PIF and MCF joints). There was no functional compromise, inflammatory signs or stiffness. The patient is otherwise healthy, without obsessive-compulsive behaviour or relevant family history. He does not practice activities requiring repetitive hand use.

On physical examination there was skin thickening in the above mentioned joints; remaining physical exam was normal.

Blood analyses (including immunological study) and hand radiographs showed no anomalies. Articular

\footnotetext{
* Correspondence: joao_alexandre@hotmail.com

${ }^{1}$ Department of Rheumatology, Hospital de Santa Maria, Lisbon, Portugal Full list of author information is available at the end of the article
}

ultrasonography revealed skin thickening around previously described joints, with no sinovitis, hydrarthrosis or bone changes.

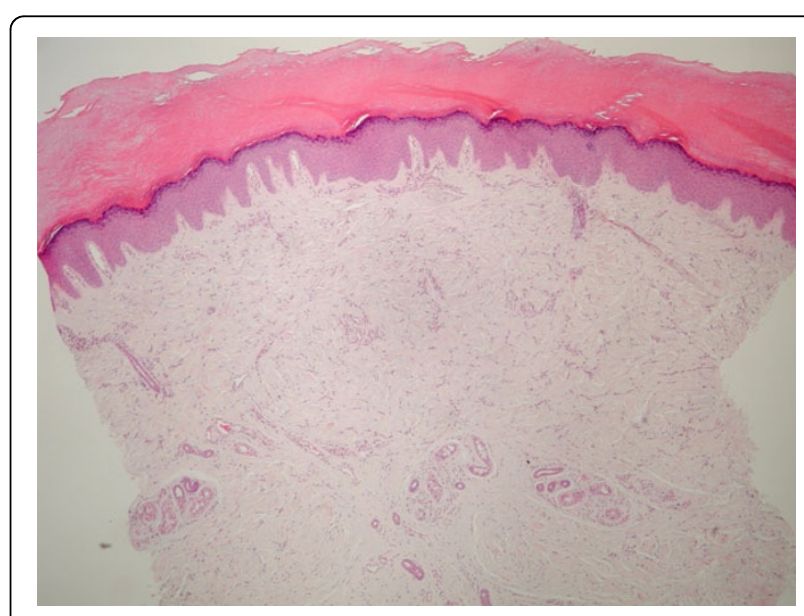

Figure 1

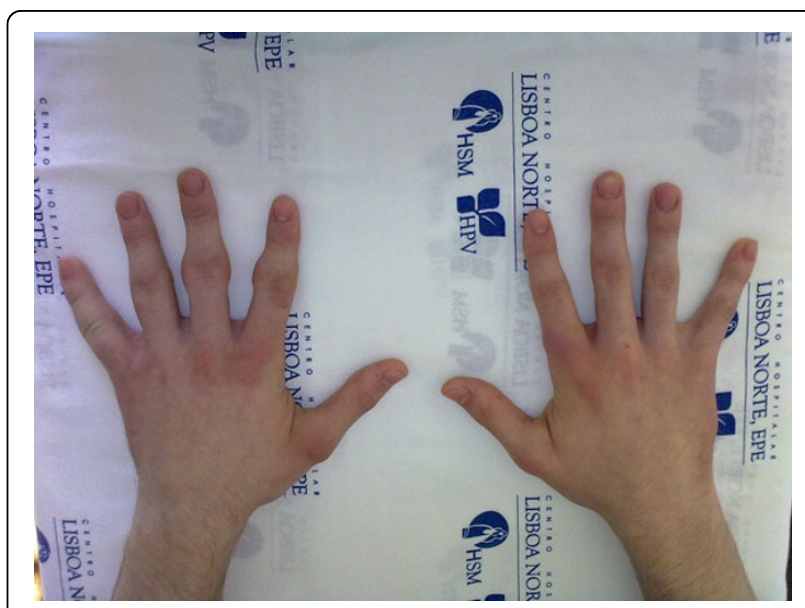

Figure 2 
Skin biopsy showed epidermal acantosis with compact hiperkeratosis, thickening of dermis collagen fibers and increased interstitial mucin.

\section{Conclusion}

Pachydermodactyly is a rare pathology that can be mistakenly diagnosed as Juvenile Idiopathic Arthritis or Knuckle Pads syndrome. (Figure 1 and 2)

\section{Author details}

'Department of Rheumatology, Hospital de Santa Maria, Lisbon, Portugal.

${ }^{2}$ Department of Dermatology, Hospital de Santa Maria, Lisbon, Portugal.

Published: 14 September 2011

doi:10.1186/1546-0096-9-S1-P224

Cite this article as: Dias et al: A case of pachydermodactyly in a 16 year-old male. Pediatric Rheumatology 2011 9(Suppl 1):P224.

Submit your next manuscript to BioMed Central and take full advantage of:

- Convenient online submission

- Thorough peer review

- No space constraints or color figure charges

- Immediate publication on acceptance

- Inclusion in PubMed, CAS, Scopus and Google Scholar

- Research which is freely available for redistribution

Submit your manuscript at www.biomedcentral.com/submit
C Biomed Central 